\title{
Mirage and Reality Interplay in Tom Tykwer's $A$ Hologram for a King
}

\author{
Anton Sutandio \\ Maranatha Christian University \\ anton.sutandio@gmail.com
}

\begin{abstract}
This article discusses 2016 film A Hologram for a King, directed by Tom Tykwer in the context of the interplay between mirage and reality. Set in Saudi Arabia, this film revolves around the story of an American consultant, Alan Clay, who attempts to sell a hollographic teleconferencing system to the king. The film is imbued with captivating and symbolic visuals that point to the interplay between mirage and reality. This article will focus on how the cinematography and mise-en-scene of the film help supporting the interplay between mirage and reality, and to show what the film comments on the interplay in regard to our contemporary world. The method used is a film scene analysis by focusing on the important scenes in the film. The findings show that the director cleverly utilizes cinematic techniques to emphasize the main theme of the film and to offer his own viewpoint on the interplay between mirage and reality.
\end{abstract}

Keywords: mirage, reality, interplay, film

\begin{abstract}
Artikel ini membahas film keluaran tahun 2016 berjudul A Hologram for a King yang disutradarai oleh Tom Tykwer dalam konteks interaksi antara khayalan dan kenyataan. Dengan berlatar tempat di Arab Saudi, film ini berkisah tentang seorang konsultan Amerika, Alan Clay, yang mencoba menjual sistem telekonferensi holografik kepada sang raja. Film ini dipenuhi dengan visual yang menawan dan simbolis yang mengarah pada interaksi antara khayalan dan kenyataan. Artikel ini akan berfokus pada bagaimana sinematografi dan mise-en-scene film membantu mendukung tema interaksi antara khayalan dan kenyataan, sekaligus ingin menunjukkan apa yang film ini coba sampaikan mengenai interaksi antara khayalan dan kenyataan dalam dunia kontemporer kita. Metode yang digunakan adalah analisis adegan film dengan fokus pada adegan-adegan penting dalam film. Temuan menunjukkan bahwa sutradara dengan cerdik menggunakan teknik sinematik untuk menekankan tema utama film dan menawarkan sudut pandangnya sendiri tentang interaksi antara khayalan dan kenyataan.
\end{abstract}

Kata kunci: khayalan, kenyataan, interaksi, film

\section{Background of the Study}

This comedy-drama tells a story about a washed-up corporate salesman, Alan Clay (Tom Hanks), who is sent to the Kingdom of Saudi Arabia to sell a hollographic communication system to the king. Along the process, Alan faces cultural clash that shakes the foundation of his way of life. At the end he lets himself immersed into the somehow surrealistic life in KSA when he meets and falls in love with a Saudi female doctor. 
According to a NY Times' review on the novel, Dave Eggers' A Hologram for a King (2012) is, "a kind of 'Death of a Globalized Salesman [story]'..." (Iyer, 2012) that revolves around a failing salesperson who loses almost everything and somehow regains his life by immersing himself in the selling of "mirage" in an utopian/dystopian-ish Kingdom of Saudi Arabia. Tom Hanks stars in the film adaptation (2016) of the novel as Alan Clay, the salesman with a "humpy" burden on his back.

The question of reality in our consistently-constructed contemporary world becomes even more important to address, especially when the pseudoreality offered by the world is usually better than the "real" reality. The world, for example through the advancement of technology, offers convenience and practicality through the invention of sophisticated gadgets, which at the same time also offers an escapism from the reality through for instance virtual reality or life simulation games. Growing consumerism also leads people to specific ideal of things such as in beauty, luxury and what it means to have a happy life. Consequently, most people live between the two worlds, and some even prefer to live outside reality. This is one issue that the film throws to the audience, on how mirage and reality often time overlap and how one has to deal with this interplay between the two. The analysis will focus on the film cinematographyon how the camera is placed, and on the mise-en-scene, especially the character, setting and props. The term mise-enscene itself means "...the framing of shots..." which include "...setting, costume, and lighting..." (Hayward 2000: 84), while acording to Bresson (1997), cinematography "...is a writing in movement and sound" (p. 2). Basically, it refers to how the camera is positioned or moved.

\section{Problems of the Study:}

a. How does the film visually depict the interplay of mirage and reality through the cinematography and mise-en-scene?

b. What does the film say about the interplay between mirage and reality in our contemporary world?

\section{Aims of the Study:}

The aims of the study is to show how the film visually depicts the interplay and reality through cinematography and mise-en-scene and to find out what the film says about the interplay in our contemporary world.

\section{Research Method}

The main object of this article is a 2016 film A Hologram for a King, directed by Tom Tykwer which will be approached through the means of film studies analysis. Firstly, multiple viewings of the film is required, secondly, to locate significant scenes that pertain to the topic of discussion and thirdly, analyze them by means of the cinematic techniques through cinematography and mise-enscene. Lastly, conclusion is drawn from the analysis.

\section{Discussion}

This article focuses on how the film's mise-en-scene support and emphasize the interplay between mirage/hologram and the reality that becomes the main point of this film. While the American represented by Clay tries to maintain his "realness" of American way of life (or which the film continuously refers to as "stuck in a good health"), people in Kingdom of Saudi Arabia (KSA) is already accustomed to the blurred boundary between the mirage or "a holographic condition" and the 
reality. The interplay between mirage and reality is symbolically and literally evident mostly through the depiction of the characters, the setting and properties used in the film.

The term mirage becomes very prominent in this film; in fact, the film main focus is how mirage is being played and contested against reality. Besides its literal meaning as an optical illusion that can easily be found in a desert area, its metaphorical meaning is also reflected in the film. From four different dictionary, mirage is defined as: "something illusory, without substance or reality" (dictionary.com); "a hope or wish that has no chance of being achieved" (dictionary.cambridge.com); "something that appears real or possible, is not in fact so" (google.dictionary.com); "something that you hope for or want but that is not possible or real" (Merriem-Webster.com). Based on the definitions, I argue that the film deals with the issue of unrealistic expectation about something.

In the beginning of the film, the audience can see how this mirageplay has already taken place during Clay's monologue when he tells the audience his lifestory. Through the use of special effect, the audience is shown how, while telling his story, Clay's life is literally disappeared in a blink of an eye, starting with his house, car, and wife. This use of special effect in which the audience can literally see everything that Clay loves disappears into thin air foreshadows and underlines the main topic of the film, that is about the interplay between mirage and reality.

\section{a. Characters}

The first aspect of the mise-enscene I would like to discuss is the characters. The interplay between the mirage and reality is shown mostly through their dialogue and actions. One example is from Yousef's account on how he falls in love with a married woman. Yousef is Clay's personal assistant and driver whom he meets at KSA. According to him, the woman is married to a much older and richer person, yet she is not happy. The condition strongly signals the woman's or her family's attempt to live better. It is clear that the woman Yousef loves sacrifices her true feeling for Yousef and is forced to marry to someone she does not love. However, she discreetly has an affair with Yousef as her true love. The love life Yousef and her lover have exemplifies the interplay between mirage and reality, because as much true as their love is towards each other, they cannot display it publicly. He almost gets into trouble for not being true to himself about his forbidden relationship with a married woman. Yet, his action moving to the village to avoid being harmed by his lover's husband shows that he everntually abandons his effort to be with the woman and lives in reality.

Despite many imageries of mirage vs reality throughout the film, I argue that Clay may be the only one who attempts to be always true to himself and others, which is quite a difficult effort considering he is in a place that does not see such effort as important. I also argue that in the end, just like his failing effort to keep the Schwinn bicycle company from going bankrupt, Clay eventually surrenders himself to the strong pull of the temptation to living large in KSA.

Both characters, albeit their contrasting background, actually share similar situation: they both in needs of money, both fall in love with a 
married woman, and both has (some) similar taste of music. As I mentioned before, unlike Clay who falls into the "sugar coating" life in KSA, Yousef is depicted to be consistently true to himself depite his anxiety of being killed by the husband of the woman whom he loves. His conviction to live in KSA no matter what is clearly seen when Clay tells him to continue studying and moves somewhere else. He firmly responds that he will not move abroad despite the harsh condition he has to face.

All other characters except Yousef is just a "mirage" to Clay. They exist to draw Clay further down to the mirage-like condition. Her wife, who only appears once in the hotel room as a fragment of Clay's imagination serves as Clay's literal mirage. Kareem, his contact, lives in his own world with his fancy clothing and sports car and is seemingly unable to acknowledge the true condition of his surroundings. The robot-like secretary whom Clay meets regularly seems to exist only as an ornament to the building. Finally, there is the absence of Clay's daughter who never appears on the scene during the actual time of Clay's narrative. The king, whose coming and going cannot be predicted, also suggests a character that manifests the mirage. Even Clay's Western's counterpart, the Danish woman, also serves as a character that tries to pull Clay into an absurd life of Westerners in KSA as seen in the orgy-like party inside the Danish embassy. The strongest of them all is Zahra, a local medical doctor who is systematically marginalized by her patriarchal environment. Clay and Zahra's love story begins with Zahra's empathy towards Clay who consults her about his cysts. Their relationship grows stronger despite the society ban, because as an unmarried couple living in KSA, they cannot even be seen together. Eventually, Clay cannot resist Zahra's strong pull and decides to temporarily live with her, which suggests Clay's making peace with the mirage-life in KSA.

The turning point of Clay's life that makes him decide to further his relationship with Zahra is during wolf hunting in the desert. In that scene, the audience do not actually see the wolf but its shadow behind some hanging clothes (see figure 1). The shot in figure 1 is a clear example of how the interplay between mirage and reality is shown. It represents a mirage because no one can tell for sure what animal lurks behind the screen, and no one can predict what it will do. We learn that the wolf seems hesitant when it is so close to the sheep. and eventually it goes away. I argue that at that critical moment for the wolf, Clay sees himself as the wolf who merely attempts to survive in the bizzare, incomprehensible situation. When he decides not to shoot the wolf, he is actually giving a chance not only for the wolf to survive, but most importantly for himself. From that moment on, Clay becomes more determined to survive or revive, in his case by making a move toward Zahra.

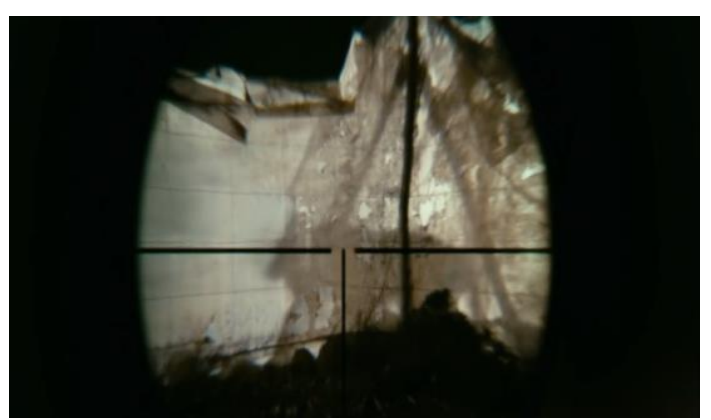

Figure 1: The wolf 
After he finally wins Zahra's heart, he further immerses himself in the mirage-like life by selling halffinished apartment located in the middle of the desert that indeed, represents yet another mirage.

\section{b. Settings and Props}

There are numerous shots of the setting throughout the film that emphasize the interplay between mirage and reality. The interplay is mostly shown through the contrasting depiction between the West and the East. In the beginning of the film, for instance, there is a scene when Clay is intentionally positioned in the middle of an airplane seating, sandwiched among men in white robes (see figure 2). The scene framing is indeed an exaggeration yet it serves as an establishing shot as where the story is and will take place. This shot also foreshadows what Clay is going to face soon.

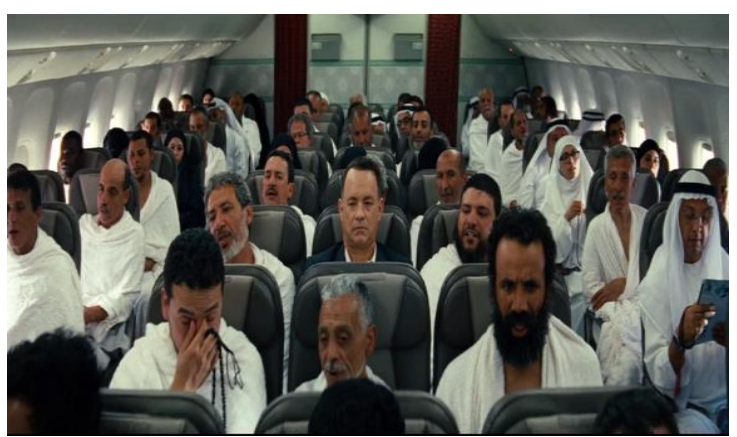

Figure 2: Clay inside an airplane

Another two shots that contrast the "civilized" west and the "exotic" east occur in the beginning of the film credit as seen in the glittering and busy American city which is juxtaposed with the empty, dry desert in figure 3 .

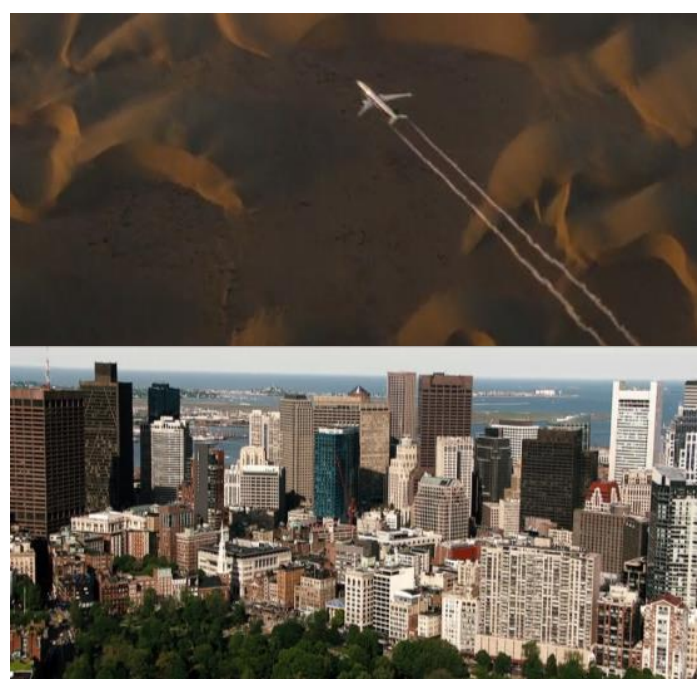

Figure 3: The contrasting desert and city

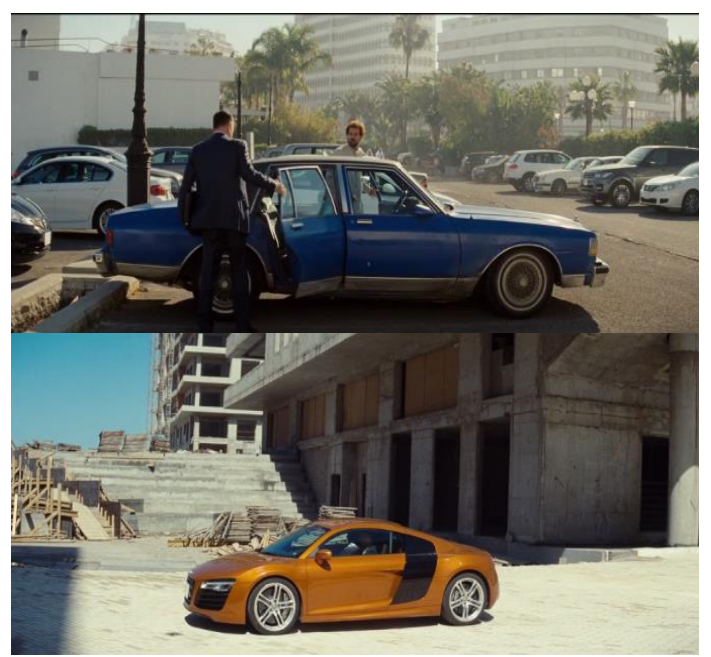

Figure 4: contrast setting and props

Figure 4 above shows playful shots that emphasize the interplay between "mirage/reality". Yousef's car in the left shot is contrasted against the expensive cars and the towering buildings. In the right shot, Kareem's sports car seems to be out of place when it is placed in the center of an unfinished empty condos. The empty building fittingly represents the mirage: the wishful thinking of the developer to have a magnificent city in the middle of the desert when he shows the miniature model of what the city will be like (see figure 5 left) 
and the vast emptiness of the desert where the city will be built (see figure 5 right). This "wishful thinking" is then negated by one of the salespersons who admits that no one yet makes any commitment to purchase any condo unit. In addition, their attempt to draw prospective buyer by placing a "fake" coming soon ads of a Western fast food restaurant chain such as KFC and Starbucks is another interplay between the promising mirage they try to create and the reality they face.

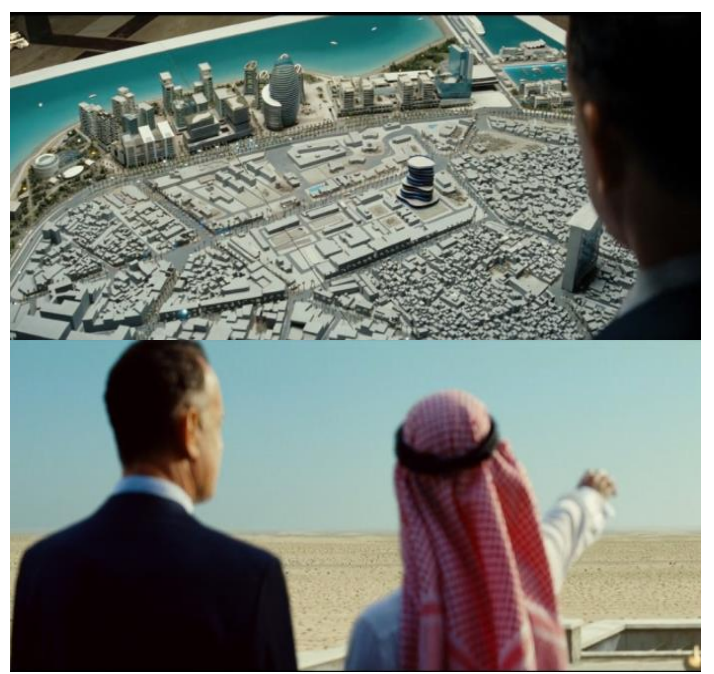

Figure 5: The dream vs the reality

Another shot that shows this mirage-like life is the shot of a lingerie shop in the middle of a market full of conservative-clad Moslem women (see figure 6). It is quite incomprehensible yet interesting visualization that puts the audience into thinking hard about how the life in KSA is actually like. We may never believe that such a store exists in a conservative community, yet there is. I argue that the purpose of this shot is to emphasize the dynamic interplay between the reality and the mirage; that there seems to be a "harmonious clash" between the modern secular and the conservative Islam.

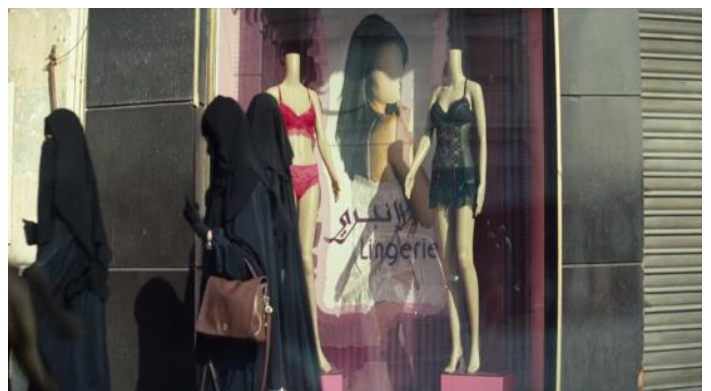

Figure 6: the conservative-clad women vs the modern lingerie

In the two shots below (see figure 7), the camerawork smartly displays two different condition of Clay during his interaction with the secretary through these two similar camera placement. The left shot shows his initial encounter with the secretary, when he is "on development" (as can be read in the background poster) and still maintain his patience. The second shot on the right is Clay who is gradually losing his patient as seen from his intimidating posture, and interestingly, his posture reveals the word "vision", which serves as foreshadowing that Clay will work to achieve this vision in the near future as a sales representative of the condos.

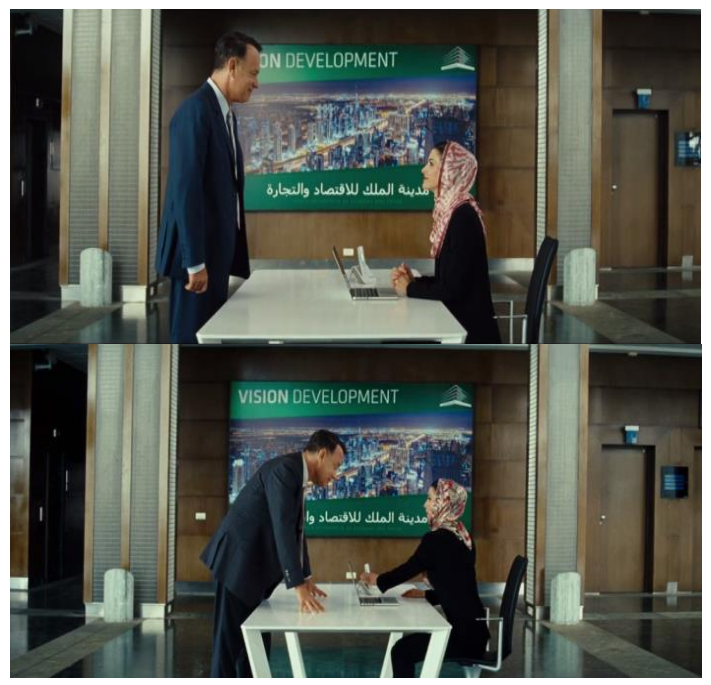

Figure 7: Clay and the secretary 
The film ends with the shot of the front door of Zahra's house that has a carving of the moon and the sun (see figure 8). The two entities represent two aspects that can never be together, yet they are there side by side, which suggests a reconciliation between two cultures that is actualized by Clay and Zahra's relationship. This final shot also cleverly displays the interplay between mirage/reality by placing them side by side.

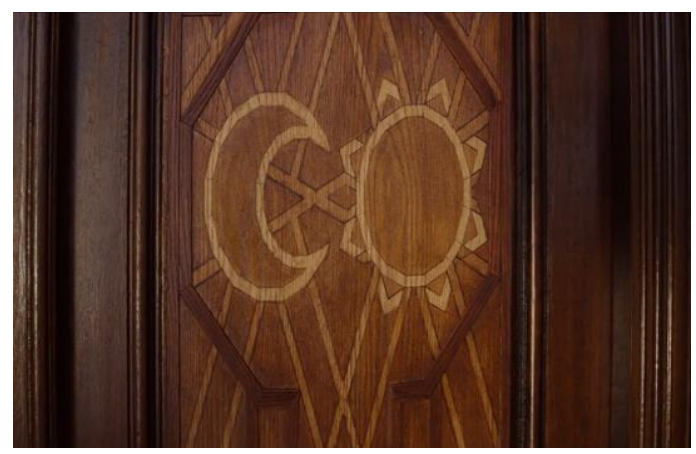

Figure 8: The sun and the moon

Indeed, the closing shot indicates that they will live in harmony despite the huge cultural differences between them. Do they finally live happily ever after? The film suggests that they will, and when reality is bitter and mirage-like life is sweet, no one can blame Clay or Zahra for choosing this path.

\section{Conclusion}

After analyzing the film cinematography and mise-en-scene, I come to a conclusion that the director has efficiently utilized them to support the interplay between mirage vs reality. The character Clay becomes the center of the interplay and it is mostly through his character that the audience can see clealry how the interplay between mirage and reality is played. His confusion and frustration when facing situations that are completely unreal to him are an example of the interplay.

The props and setting also play significant parts in emphasizing the interplay through repetitive juxtaposition of scenes that suggests the clash between reality and the mirage. Sometimes the scenes show contrast objects to further generate a dreamlike feeling, for example in the shot of a bikini shop in the place when women are not allowed to expose any part of their body, or in the opening shot inside the plane cabin when Clay is surrounded by people in white robes. The final shot of the house door that depicts the moon and the sun becomes a symbol of reconciliation, and at the same time suggesting that everything is possible as long as someone is willing to surrender oneself to the dreamlike or unreal situation and and just "follow where the river flows," like what Clay eventually does.

\section{References}

Arndt, S. (et.al.) (Producers), \& Tykwer, T. (Director). (2016). A Hologram for the King [Motion Picture]. United States: Lionsgate.

Bresson, R. (1997). Notes on the Cinematographer. Los Angeles: Green Integer.

Hayward, S. (2000). Cinema Studies: The Key Concepts. London: Routledge.

Iyer, P.(2012, July 19). Desert Pitch. New York Times. Retrieved from http://www.

nytimes.com/2012/07/22/books/re view/a-hologram-for-the-king-bydave-eggers.html?_r=0. 
Mirage. (n.d.). In Cambridge Dictionary.

Retrieved

from

http://www.dictionary.com

/browse/mirage.

Mirage. (n.d.). In Dictionary.com.

Retrieved from

http://www.dictionary.com/browse/mirag

e.

Mirage. (n.d.). In Google. Retrieved from https://www.google.co.id/search? $\mathrm{q}=$ mirage+definiton

$\&$ oq $=$ mirage $+\&$ aqs $=$ chrome $.0 .69 \mathrm{i}$ 5912j69i57j013.1743j0j4\&sourcei

$\mathrm{d}=$ chrome \&ie $=U T F-8$.

Mirage. (n.d.). In Merriam-Webster. Retrieved from http://www.merriam-webster.com /dictionary/mirage. 